\title{
Research Paper Millet a sustainable crop: Growth and instability in area and production of millets
}

See end of the paper for authors' affiliations

Correspondence to :

Neelamma R. Kolageri

Department of Agribusiness Management, College of Agriculture, University of Agricultural Sciences,

Dharwad (Karnataka)

India

Email : neelrk6@gmail.

com

Paper History :

Received : 03.03.2018;

Revised : 20.03.2018,

Accepted : 24.04.2018
ABSTRACT : The millet belong to a group of small size food grains, mainly grown around the world for food and fodder. In this paper an attempt has been made to analyse the trend in area and production of millets across country including Karnataka. India is the leading producer in the world millet production, followed by the African countries of Nigeria and Niger. Total food grain production in the country was of about $271.98 \mathrm{MT}$ and cereals production was 44.34 million tonnes. The growth rate and instability index in millet's area and production in India and Karnataka has been examined using secondary data for the period of 10 years, from 2006-07 to 2015-16. This study is confined to major millets (sorghum/Jowar, Bajra and finger millet) and minor millets (referred as small millets). From the analysis it is found that all the millets sorghum, Bajra, finger millet and small millets had negative growth rate -4.02 per cent, -3.41 per cent, -1.47 per cent -5.68 per cent, respectively. Similarly the production growth rate of sorghum and small millets were found negative, bajra and finger millets had least positive growth rate. It is also found from the analysis that the instability index of millet area was lower than the instability index of millet production. It can be concluded that the declined growth rate of millet cultivation may be due to various factors like crop substitution, less awareness about the millet and its health benefits, low price to the millets compared to other crops. Including millets in everyday food routine can enhances the health benefits.

KEY WORDS : Instability, Growth, Health, Millets, Production

How To Cite This PAPer : Kolageri, Neelamma R. and Israel, K. Shiny (2018). Millet a sustainable crop: Growth and instability in area and production of millets. Internat. Res. J. Agric. Eco. \& Stat., 9 (2) : 253-256, DOI : 10.15740/HAS/IRJAES/9.2/253-256. Copyright@ 2018: Hind Agri-Horticultural Society. 